are not widely enrolled in public universities, as admission quotas there remain the same.

To conclude, the process of founding XMUM reflects a blend of recent educational developments in Malaysia, ASEAN, and China. Even though the branch campus has had a successful start, the expansion of the globalized education market in Asia will mean intense competition in the future-but for that the university is well prepared.

DOI: http://dx.doi.org/10.60I7/ihe.2018.95.10697.

\section{Forget the Competition Trope}

\section{Creso M. SÁ}

Creso M. Sá is professor of higher education and director of the Centre for the Study of Canadian and International Higher Education at the Ontario Institute for Studies of Education, University of Toronto, Canada.E-mail:c.sa@utoronto.ca.

Ptersion rior to the rise of nationalist populism raising the specter of a dampening of internationalization in higher education, one of the most common tropes in related debates was the idea that there is a global race for international students. The evidence used to support this idea usually includes scholarship programs and international student recruitment schemes, which have been well documented over the years. Both academic and policy literature emphasize the transnational scale of this competition and position it as critical for economic success. Governments have thus been assumed to be intentionally seeking to win the global race by enrolling more students from abroad in their higher education institutions.

What is wrong with this picture? If governments are competing, in the same way that they do when it comes to other areas such as trade and international affairs, we would expect to see some kind of long-term pattern in their actions. That is what University of Toronto doctoral student Emma Sabzalieva and I sought to figure out: have major host countries in the Anglosphere actually engaged in a global race to attract the best international students?

We examined how public policy in Australia, Canada, England, and the United States dealt with international students in higher education between 2000 and 2016 . We also looked at how policy frameworks impacting such students changed over time. These four countries enrolled around 40 percent of all international students in 20I5. For each country, we carried out a case study that traced changes in relevant policy over the period investigated, and identified the events associated with policy change. We interpreted the passing of legislation, the introduction of new programs, and relevant policy changes against the political background of each country. In our paper, "The politics of the great brain race: public policy and international student recruitment in Australia, Canada, England and the USA," recently published in Higher Education, we argue that none of these major countries have dealt coherently with international student attraction and retention. Furthermore, the long-term outlook required to cope with the assumed global competition for students is glaringly absent.

\section{We examined how public policy in Aus- tralia, Canada, England, and the United States dealt with international students in higher education between 2000 and 2016.}

\section{INCONSISTENT AND UNCOORDINATED}

Our analysis shows that the long-term growth in international student enrollment across the four countries is largely decoupled from policy developments. Although there have been occasional fluctuations, international student enrollment has steadily increased in the four countries during the period in focus, and quite substantially: 226 percent in Canada, IIo percent in Australia, 8I percent in England, and 48 percent in the United States.

A different picture emerges from a review of policies in several sectors that shape the ability of international students to join a higher education institution and potentially remain in the four countries. Despite a shared policy rhetoric that evokes maintaining global competitiveness and attracting talent, none of the countries have maintained a consistent path of facilitating international student recruitment or retention, nor have they sought to pursue improvements in their policies and regulations.

In terms of immigration for example, restrictions on international students have been tightened at different points in time, and well before the onset of Brexit and the Trump administration. In England, for instance, changes to its point-based immigration system early in this decade pe- 
nalized international students by restricting time limits on student visas, working rights, and the number of courses that they could take. Similarly, Canada's introduction of the Express Entry selection system in 2015, aiming at streamlining the visa application process and facilitating integration in the labor market, made it more competitive for international students to seek permanent residency. In both cases, the governments in power claimed to be competing for the best and brightest, while making it hard for international students to subsist or to become residents.

Looking at a range of areas such as health care, employment rules, regulations on dependents, financial aid, tuition fees, and taxation, it becomes clear that none of the countries displayed a pattern toward facilitating international student mobility. Public policy in those and other areas impact international students, and they span government agencies or ministries. Isolating policy to a single ministry overlooks the complexity required to manage issues connected to international students. Hence, coordination both across government and with the higher education sector is needed to address constraints on international students. The Prime Minister's Initiative in England and the recent strategy for international education in Australia are examples of policy initiatives that sought a cross-sectoral approach. For the most part, however, policy coordination in this area remains elusive.

\section{CONCLUSION}

If policy makers in the Anglosphere were intentionally engaging in a global race to recruit international students, one would expect to see policy changes in a certain direction. That is expected from countries that compete in a certain industry: decisive action is taken to maximize one's comparative advantage. In reality, policy changes that are consequential for the recruitment and possible retention of international students have been anything but consistent or convergent over the first $\mathrm{I} 6$ years in this century. While there may be similarities in the discourse governments use, invariably endorsing the ambition of universities to recruit students globally, over time policy action has followed divergent logics. In this context, international student numbers in the four countries have arguably grown despite rather than because of political and policy changes.

DOI: http://dx.doi.org/I0.60I7/ihe.2018.95.10683

\section{Measuring Education Quality in Global Rankings: What's the Likelihood?}

\section{Philip G. Altbach and Ellen Hazelkorn}

Philip G. Altbach is research professor and founding director of the Center for International Higher Education, Boston College, US. E-mail: altbach@bc.edu. Ellen Hazelkorn is emerita professor and director, Higher Education Policy Research Unit, Dublin Institute of Technology, Ireland, and partner, BH Associates, Education Consultants. E-mail: ellen.hazelkorn@dit.ie.

$T$

The most influential global academic rankings-the highly influential Shanghai Academic Rankings of World Universities (ARWU), Times Higher Education (THE) World University Rankings, and QS Top University Rankings-have been in existence for more than a decade and are now a major force in shaping higher education worldwide. One of their key purposes is to demonstrate the world's best universities, based on their own criteria. However, they consider fewer than 5 percent of the more than 25,000 academic institutions worldwide. The rankings are influential—students make decisions on where to study; some governments allocate funds; and universities struggle to improve their position in them.

From the beginning, these rankings have focused primarily on research productivity. Reputational measures are also included in the QS and THE rankings, but these measures remain controversial due to low response rates that accentuate biases and limited perspective. Each survey indicator is considered independently, where multicollinearity is more persuasive-in other words, doctoral students, citations, research income, internationalization etc. are highly interdependent. Allowing for some overlap, research-related indicators constitute approximately 70 percent of the total score for QS while reputation influences 50 percent. Both ARWU and THE are Ioo percent based on research/ research-related indicators.

\section{Teaching/Learning Enter the Rankings Equation}

Without question, teaching is the fundamental mission of most higher education institutions; with few exceptions, undergraduates comprise the majority of students enrolled in higher education worldwide. However, the "world-class" concept is derived from those universities that score highest in global rankings. This is relatively easy to explain. 